\title{
CESIS
}

Electronic Working Paper Series

\section{Paper 103.}

Entrepreneurship and Local Growth

A comparison of the U.S. and Sweden

August 2007

(1) 


\begin{abstract}
The U.S. is traditionally viewed as an economy driven by entrepreneurs, whereas the Swedish model is associated with high welfare ambitions and less focus on entrepreneurial activities. This paper seeks to empirically investigate whether the connection between entrepreneurship and growth at the regional level differs between the U.S. and Sweden. By regressing annual entrepreneurship on regional employment growth (and controlling for other conceivable variables impacting employment growth) entrepreneurship is shown to be positively and significantly associated with regional growth in both countries in the 1990s. Still, the result is more robust for the U.S. Other important variables for regional growth is business density and, in the case of the U.S., educational levels and internal scale economies.
\end{abstract}

Keywords: Entrepreneurship, Knowledge spillovers, Regional growth JEL: M13, O57, R11 


\section{Introduction}

The objective of this paper is to empirically examine how entrepreneurship impact growth in two countries - Sweden and the U.S - characterized by conspicuous differences in traditions as well as the overall institutional set up. Entrepreneurship does not comply with neoclassic theories where growth was modelled as a function of labour and capital inputs (Solow, 1956). However, empirical investigations showed that capital and labour indeed only accounted for a smaller part of the fluctuations in growth rates (Solow 1957).

A major step forward was taken as the endogenous growth theories were introduced, providing a link between knowledge accumulation and growth (Romer, 1986; Lucas, 1988). Knowledge was explicitly implemented as an additional input in production, which was then theoretically shown to be the main driver of economic growth since it had both a direct and indirect impact. The latter occurred due to the non-excludability and nonrivalry characteristic of part of the knowledge stock, allowing knowledge to spill over to different parts of the economy. This spillover effect implied that productivity increased as more individuals and firms could exploit available knowledge. Economic growth could hence be sustained despite decreasing returns to capital and labour.

Parallel to the advances in the endogenous growth literature, economic geography models have shown that concentrated production structures facilitate knowledge spillovers through close interaction between individuals and firms (von Hippel, 1994; Glaeser et al, 1992). Such interactions cause knowledge leakage and thus allow more knowledge to be used in production as compared to less dense locations. However, different regions are not only distinguished by the degree of agglomerated production, but also by differences in the industrial compositions which is likely to influence the extent of knowledge spillovers. Instead of having a region dominated by one, or a few separated industries, spillovers and growth may benefit from a variety of interrelated industries and competitive markets (Jacobs, 
1969; Glaeser et al., 1992; Feldman and Audretsch, 1999; Acs et al., 2002; Braunerhjelm and Borgman, 2006). Hence, there are obvious reasons why knowledge spillovers and economic growth should be analysed at the regional level.

Economic research has thus focused on the importance of knowledge and the fact that it spills over through the interaction between economic agents. However, this is not necessarily enough to promote growth. Given a region where knowledge is produced in abundance (as measured by R\&D) the spillovers of knowledge still need to be turned into economic prospering businesses (Arrow 1962). The entrepreneur is one such mechanism. ${ }^{1}$ She/he can be viewed as a missing link between knowledge and growth that recognises business opportunities and commercialises knowledge through new firm start-ups and thus utilising knowledge that is not exploited in incumbent firms (Acs, et al., 2004). Hence, a positive relationship between new firm start-ups and regional growth can be expected.

The purpose of this paper is to empirically investigate the relationship between entrepreneurship, represented by start-ups, and regional growth defined in terms of employment. Previous studies for particularly the U.S. contend a positive relationship between entrepreneurship and growth (Acs and Armington, 2004; Braunerhjelm, 2007). However, by comparing the U.S., generally considered to be an entrepreneurially driven economy, and Sweden that represents the traditional welfare state, this study shed further insights into the relationship between entrepreneurship and growth.

In the next section follows a brief discussion of the theoretical foundations concerning differences in regional economic growth rates. In section three the data that will be used in the empirical analysis is presented. Section four sets up the econometric model to be estimated, and section five presents the results. Finally section six provides the conclusions.

\footnotetext{
${ }^{1}$ Another mechanism is labour mobility (Moen, 2005), but here we focus on entrepreneurial skill.
} 


\section{Sources of diverging regional employment growth}

As mentioned in the previous section endogenous growth theories emphasises knowledge as the prime source of differences in growth rates. One part of knowledge is individual specific and embodied in humans, referred to as human capital. ${ }^{2}$ A higher regional level of human capital facilitates more efficient production and business development, which in turn is likely to lead to growth in employment (Rauch, 1993).

When production is densely located the scope for significant knowledge spillovers increases (Orlando, 2000; Autant-Berrnard, 2001; Döring and Schnellenbach, 2006), which gives rise to positive externalities - often referred to as non-pecuniary externalities. As knowledge spills over to adjacent firms and individuals, more knowledge is available for use in production. This implies that the growth effects of knowledge to a large extent are geographically bounded, which concurs with empirical evidence (Karlsson et al., 2006). Agglomerations, with associated interaction between agents, can also benefit regional growth by spurring creativity (Florida, 2002). Another outlet for agglomeration to impact employment growth is through pecuniary externalities. For example when firms locate near each other supplier - buyer relationship evolves which foster specialization, reduce prices and increase competition which attracts labour and capital and thus nourish a market for both inputs and outputs (Porter, 1990; Wolfe, 2006).

The entrepreneur enters the arena when knowledge creates opportunities for commercially viable actions (Acs et al., 2007). The entrepreneur serves several purposes. The first is to recognize an opportunity that might otherwise have gone unnoticed (Schumpeter, 1911; Koppl and Minniti, 2003). The second is to act on opportunities in spite of uncertainty (Knight, 1921). When incumbent firms do not absorb all its knowledge and does not fully

\footnotetext{
${ }^{2}$ See the literature review by Audretsch and Feldman (2004), or Döring and Schnellenbach (2006).
} 
exploit the opportunities that are generated by knowledge investments, entrepreneurial individuals will pursuit business opportunities through new firm formation (Shane, 2000; Acs et al, 2004). These firms will produce output and increase employment growth. There is no reason to assume that individuals endowed with "the entrepreneurial spirit" is evenly distributed over geographic regions (Reynolds et al., 2001), and even if they were, differences in regional and national policies will influence the start-up rates (Baumol, 1990) and thus also the pattern of employment growth. ${ }^{3}$

There are strong reasons to believe that the relationship between start-up rates and employment growth differ between the U.S. and Sweden. Based on previous research, such differences can arise as policies shape diverging habits and traditional patterns, as well as current institutional factors (tax systems, social security etc), which affect both the levels and structure of entrepreneurial activity (Carree and Thurik, 2003; Cullen and Gordon, 2006; Baumol, 1990). Moreover, these factors seem to shape the (tacit) knowledge of how to commercialize ideas, which constitutes the link between entrepreneurship and growth.

On the basis of previous findings referred to above, the following model explaining differences in regional employment growth can be formulated,

Employment Growth r,$t=f\left(H_{r, t}, A_{r, t}, E_{r, t}, \gamma_{r, t}, \phi_{r, t-i}\right)$

where the subscripts $\mathrm{r}$ denotes region, and t denotes time. $\mathrm{H}$ refer to human capital, A to agglomeration effects, E denote entrepreneurial activity and $\gamma$ is a vector of variables relating to the regional production structure such as scale effects in regional firms and regional absorption capacity. $\phi$ is a vector containing possible lags of the explanatory variables.

\footnotetext{
${ }^{3}$ See Braunerhjelm (2007) for a survey.
} 


\section{Data and variables}

\subsection{Data}

This study uses data for the U.S. and Sweden covering the years 1993 - 1999. The U.S. data is collected from the Longitudinal Establishment and Enterprise Microdata (LEEM) file compiled by the Bureau of the Census, Washington, DC. The original database uses establishments as unit of measurement; however, in this study data are aggregated to the regional level. The spatial definition used is Labour Market Areas (LMAs), which are constructed based on commuting distances. There are 394 LMAs in the U.S. and they are constructed according to the work of Tolbert and Sizer (1996). Available data from the LEEM file covers all establishments in the non-farm US private sector with employees for the years $1993-1999$.

Data for Sweden comes from Statistics Sweden (SCB) and covers the whole population of establishments in Sweden every third year between 1993 and 1999. The data is cross tabulated over regions, industries (at the two-digit ISIC level) and establishment size, although this study will use regional LMA aggregates to facilitate comparisons with the U.S. data. Unlike the U.S. data Statistics Sweden does not exclude the public sector from database. Since it is possible to distribute the data on industries, one could choose to exclude certain sectors with a large public presence. However, since this would be an arbitrary selection that certainly would exclude some private establishments as well the econometric analysis will use data covering the whole Swedish economy.

Since growth is at focus in the present study, figure 1 illustrates growth at the aggregate level (GDP) between 1980 and 2000 for both the U.S. and Sweden. GDP is measured in millions of 1995 PPP dollars, and indexed so that 1980 equals 100. The U.S. is seen to have a slight kink in the early 1990's, whereas the time period investigated in this paper, 1993 - 1999, is defined by a stable GDP growth period. In Sweden, the recession in the 
early 1990’s was more prolonged with negative growth between 1990 and 1993. On the other hand, in the later half of the 1990's Sweden benefited from the international ICT boom as well as structural reforms in early 1990's resulting in several years of above normal growth (Söderström et al., 2001).

As can be seen in figure 2, the high unemployment rates caused by the early 90’s recession did not decrease in Sweden until after 1997, whereas the stable U.S. GDP growth is also reflected in the steady decline in unemployment. Thus, both $1993-1996$ and the ensuing three year period was characterized by steady economic growth in the U.S. whereas in Sweden the first three years was still very much influenced by the early 1990’s recession, while the second time period was defined by above average growth.

\subsection{Employment Growth and Entrepreneurship}

The key measure in this study is the compounded average annual regional employment growth rate over a period of $i$ years, which is calculated as:

Employmentgrowth $_{r, t}=\left(\text { Employment }_{r, t+i} / \text { Employment }_{r, t}\right)^{1 / i}-1$

For the two time periods 1993 - 1996 and 1996 - 1999, the average regional employment growth in the U.S. is 2.4 percent, with a highest growth rate of 9.9 percent and lowest of -2.4 percent. In Sweden for the periods 1993 - 1996 and 1996 - 1999 the corresponding numbers are $0.3,3.9$ and -6.7 percent. Hence, on average employment grew eight times more in the U.S. than in Sweden. This coincides with the previous found pattern indicating that the U.S. has had a more positive GDP growth trend during the 1990's. The 10 regions with strongest positive and negative growth trends between 1993 and 1999 are presented in table 1, as well as their population trends. The stronger growth trend for U.S. regions is also visible in the 
table and in fact only the Swedish region with the strongest employment growth between 1993 and 1999 would qualify for the list of the ten strongest U.S. regions.

The opposite pattern emerges when we focus on the other end of the spectrum. There, the Swedish regions have the strongest (negative) growth and none of the U.S. regions would qualify on the Swedish bottom ten list. It is also clear (most so in the U.S.) that the regions with high employment growth have had a positive entry of population. Similarly, many of the regions with the most negative growth have had negative net migration. Table 1 also illustrate that when the employment growth is adjusted with the population flow the top regions still display positive growth numbers of a significant magnitude where as the opposite is true for the bottom ten regions. It thus seems that although population correlates with employment, it cannot alone account for employment growth.

Defining, let alone measuring, entrepreneurship is a complicated issue that has given rise to much research. ${ }^{4}$ The present study will follow previous research and available measurements. One usual way to capture entrepreneurship is to measure start-ups. According to Carree and Thurik (2003, p. 447) "Newness through start-ups and innovations as well as competition are the most relevant factors linking entrepreneurship to economic growth”. Start-ups have also been the focus of many studies linking entrepreneurial activity to growth (Reynolds, 1999; Audretsch and Fritsch, 1996, 2002; Acs and Armington, 2004). ${ }^{5}$ When focusing on U.S. data the definition of entrepreneurial activity will be the regional $i$-year average start-up rate, weighted by the regional labour force. This is the same measure as used by Acs and Armington (2004).

\footnotetext{
${ }^{4}$ For some examples of different views concerning definition and measurements see Cooper (2003); Sarasvathy et al. (2003); Carree and Thurik (2003); Hébert and Link (1989); Banerjee and Newman (1993); Iyigun and Owen (1999).

${ }^{5}$ However, start-ups has also been criticised as a measure of entrepreneurship since it, for example, only show one side of market turbulence which is vital for Schumpeter's (1911) definition of entrepreneurs as engines for creative destructiveness.
} 
The Swedish data do not provide age distribution of establishments, but instead the size distribution. Entrepreneurship will therefore be measured as the change in a regions number of establishments with zero or one employee over $i$ years, weighted by the total number of employed in the region. The reason for only using establishments with zero or one employee when creating this measure is that small business has a special significance in entrepreneurship research. Again referring to Carree and Thurik (2003, p. 458) "In case a region has a larger share of small firms when compared to another region this could indicate a higher level of entrepreneurial activity. [...] In developed economies the rate of selfemployment will be related to the extent of entrepreneurial activity. New firms usually start with a phase of self-employment”. The Swedish measure can thus be viewed as net entry of establishments that on average are more closely related to entrepreneurial activity than the standard establishment.

At this point two sources of movements in this measure is worth acknowledging. The first is that some small businesses grow from year $t$ to year $t+i$ and take on more employees. These establishments will cause the entrepreneurship measurement to decrease compared to if they would have been less successful and not taking on further employees. The second is that some businesses will decrease its employees from year $t$ to year $t+i$, from more than one employee to one or zero employees. This render a higher entrepreneurship measure, when in fact the only thing that has happened is that an older firm has been downsized. These are both indications that this entrepreneurship measure is not perfect. However, in the first case it causes the measure to decrease more than desirable at the same time as regional employment growth increases, while in the second case it cause the entrepreneurship measure to increase more than desirable at the same time as regional employment growth decreases. Thus, both movements create a negative bias in the relationship between entrepreneurship and employment growth meaning that if these dynamics has a significant effect any obtained 
positive relationship between entrepreneurship and employment growth tend to underestimate the true effect.

Table 2 provides an account of the 10 regions with the highest and lowest, respectively, average entrepreneurial activity between the years 1993 - 1999, and their respective employment growth rates. For the U.S. data the entrepreneurship column refers to the regional average annual birth rate, divided by the regional labour force (and scaled up by 1000). Thus, for the region Glenwood Springs there were, on average 9.5 start-ups per 1000 persons in the labour force during each year between 1993 and 1999. For the Swedish data the entrepreneurship column refers to the average annual change in a region's number of establishments with zero or one employee per 100 employed between 1993 and 1999. Thus, for the region Arvika there was an average annual increase of 2.8 establishments with zero or one employee per 100 employed during the years 1993 to 1999. From the table it is obvious that the regions with higher entrepreneurial activity have had higher employment growth rates over the period. For the ten American regions with highest entrepreneurship the average annual employment growth rate were 4.1, whereas for the regions with the lowest entrepreneurship the average annual growth rate was only 1.3. The corresponding figures for the Swedish regions are 2.6 and -1.4 .

Figure 3 illustrates the correlation between entrepreneurship and employment growth in U.S. regions between 1993 and 1996, which displays an obvious positive pattern. As can be seen from figure 4, the same pattern also emerges in the following three years. In Sweden (figure 5) only a slightly positive pattern can be seen over the years 1993 - 1996, when many of the regions display negative growth patterns. However between 1996 and 1999, when regional growth rates resurged and the level of entrepreneurship rose significantly, a clear positive correlation is seen also in Sweden (figure 6). 


\section{Hypotheses and Econometric Model}

\subsection{Hypotheses}

Besides testing for a positive relationship between regional employment growth (dependent variable) and entrepreneurship, we will use several other variables to control for factors potentially influencing regional growth. The density of regional production structure will be controlled for through two variables. The first refers to regional specialization measured as the number of establishments in a region as a fraction of regional population, divided by the corresponding measure at the country level. Thus, if one region has more/less establishments per person than the country average this specialization variable is above/below one. The second variable, business density, measures the number of establishments in a region as a fraction of the region's area. Both variables are assumed to be positively related to regional employment growth since they do not only signal a region’s potential for knowledge spillovers, but the larger number of establishment should also be associated with pecuniary spillovers. Business density has been shown to have a positive connection to regional growth, and is expected to positively influence employment growth. ${ }^{6}$

Human capital is proxied by two educational attainment variables measuring the share of all adults in a region over 25 years with high school degrees (basic education) or collage degrees (high education) in the U.S. 1990. Due to restricted data availability the corresponding measure for Sweden use total number of employed as weights. Human capital has previously been shown to correlate positively with regional growth rates, ${ }^{7}$ and is expected to display a similar relationship in this study.

Finally, the regressions will also include two control measurements relating to the regional firms’ ability to exploit scale economies and the regions absorption capacity

\footnotetext{
${ }^{6}$ See, for example, Ciccone and Hall (1996); Ciccone, (2002); Acs and Armington (2004).

${ }^{7}$ See, for example, Ciccone and Hall (1996); Simon and Nardinelli, (2002); Braunerhjelm and Borgman (2004); Karlsson and Pettersson (2005).
} 
respectively. The average number of employees in the region's establishments defines the former, and the regional population, indicating the regions ability to take on new ventures and growing economic activity, defines the latter. It could be argued that the size variable may have a positive association with employment growth, i.e. when relating to economies of scale. However, since we have already established that entrepreneurial activity often takes place in firms with few employees a higher number of employed in the average firm can also signal low regional entrepreneurship rates and thus impede employment growth. Hence, a priori, this variable could show both a positive and negative relation with regional employment growth. Increasing regional population has been shown to raise productivity (Rice, et al, 2006). However, the relationship to employment growth is not assured. Neither is the lag structure, hence there is no certain prediction regarding the expected sign of this coefficient. All variables, their definitions, summary statistics and expected signs are shown in the appendix (tables A1a (U.S.) and A1b (Sweden).

\subsection{Econometric model}

Given the variables above, the regression estimated in this paper can be formulated as:

Employmentgrowth $_{r, t}=\alpha+\beta_{1}$ Entrepreneurship $_{r, t}+\beta_{2}$ Specialization $_{r, t}$

$+\beta_{3}$ B.Density $_{r, t}+\beta_{4}$ Education $_{r, t}+\beta_{5}$ Size $_{r, t}+\beta_{6}$ Population $_{r, t}+\varepsilon_{r, t}$

where Employment growth refers to the compounded average annual regional employment growth rate between year $t$ and year $t+i$. Entrepreneurship refers to the average annual entrepreneurial activity between year $t$ and year $t+i$ as previously defined. Because of multicollinearity issues Education refers to either basic education or high education. The regressions will be preformed using a standard OLS technique and controlling for 
heteroscedastisity by White's (1980) method. Except for heteroscedastisity the standard error is assumed to exhibit standard properties. ${ }^{8}$ All variables will be estimated in their standardized forms. Thus the beta coefficients denote the share of the control variable's standard deviation that is reflected in the deviation of the regional employment growth variable from its average.

Regarding simultaneity one might argue that an increase in regional employment growth can enhance entrepreneurial activity in the region. However, there is no theoretical backing for the beliefs that increased labour force participation should lead to an upward surge in newly formed establishments in neither the Solow (1956) nor the Romer (1990) model. To address this issue we will also present estimates using lagged control variables on regional employment growth thus further decreasing the probability of simultaneity since this would require that present employment growth cause the past movements in net entry of small establishments (for Sweden) and birth rates of firms (for U.S.). This specification will also allow some insights into the lag mechanisms of the relationship between the independent and dependent variables.

\section{Regression Results}

Multicorrelation does not seem to be a problem in these regressions, with the exception of the size and business density variables with the U.S. data and the size and specialization variables with the Swedish data. When these correlations influences the results to any significant degree the impact of running the regressions without one, or more, of these variables will be described in the text. ${ }^{9}$

\footnotetext{
${ }^{8}$ When data is regionally distributed spatial autocorrelation is always an issue. Using Geary’s test (for more information see Cliff and Ord, 1973) on Swedish data the null hypothesis of no spatial autocorrelation could not be rejected. U.S. data is not tested here. However, the LMA regions are well documented and developed in order to avoid spill over mechanisms in analysis such as present (Tolbert and Sizer, 1996; Acs and Armington, 2004).

${ }^{9}$ Correlation tables and additional regressions are available upon request.
} 
Furthermore, the covariance matrices show that both countries display a significant positive correlation between entrepreneurship and employment growth. There are also some apparent differences between the two economies, as visible in the dissimilar covariations of specialization, higher education and population to entrepreneurship. Regional absorptive capacity and especially a larger share of highly educated persons in the labour force correlates positively with entrepreneurship in the U.S. whereas specialization seem to be of greater importance for Swedish entrepreneurship. These differences can stem from either the different constructions of the entrepreneurship variable, or structural differences in the economies. Considering that the same variables display similar disparities in the correlation with employment growth, the latter explanation seems plausible.

Turning the attention to the regression results, table 3 presents the results from the regressions using basic education as human capital variable. Column 1 refers to the regression on U.S. data where $t$ equals 1993 and $i$ the ensuing three years (see variable definitions). Column 2 refers to the corresponding regression run on Swedish data. Column 3 and 4 shows U.S. and Swedish data, respectively, where $t$ equals 1996 and $i$ again represent three years. Finally column 5 and 6 presents the extended time period in the U.S. and Sweden where $t$ refers to 1993 and $i 6$ years.

According to column 1 entrepreneurship is shown to be strongly positively associated with regional employment growth between the years 1993 - 1996 in the U.S., as expected. Given that employment growth has a standard deviation of 0.015 and entrepreneurship has 0.893 , the coefficient of 0.442 implies that an additional firm birth per 1000 persons in a region is associated with an increase in regional employment growth by three fifths of a percentage point. ${ }^{10}$ These results are on similar levels, although slightly lower than those reported by Acs and Armington (2004). The specialization measure is positive

\footnotetext{
${ }^{10}$ Calculation: $(0.893 * 0.442) * 0.015=0.0059$.
} 
although insignificant whereas the business density is both negative and significant. However, when controlling for the multicollinearity issue by re-running the regression without the size variable, business density turns positive and insignificant. ${ }^{11}$ All other coefficients are basically unchanged by this modification. The human capital variable is positive, but not significant, whereas the average size of establishments is both positive and significant. Finally, the coefficient for regional population is negative and significant, signalling that regions with smaller than average population have had the largest growth rates.

In column 2 Sweden also display a positive coefficient for entrepreneurship, although insignificant. In fact, all variables show up with an insignificant connection with employment growth between 1993 and 1996. One explanation for this is that Sweden implements a different set of policies that might affect both the level of entrepreneurship and its connection to growth. This relates to the findings of Davis and Henrekson (1999) who noted that the Swedish institutional environment prior to the economic crisis in the early 1990’s disfavoured small and newly established firms compared with similar establishments in the U.S. Another explanation can be found in figure 1 and 2, which show that this period was characterized by unusual low growth rates, especially when defined as employment growth. This can also be a source for the general weak significance levels and below average r-square value. Adopting the same methodology as in the case of the U.S., a significant entrepreneurship coefficient of 0.364 would have signalled that one extra establishment with zero or one employee per 100 employed is associated with almost one fifth of a percentage point increase in regional employment growth. ${ }^{12}$

By column 3 it is clear that entrepreneurship is both positive and significant also for the period 1996 - 1999 in the U.S., although this time with a slightly lower coefficient (which is true even when accounting for the different standard deviations of the employment

\footnotetext{
${ }^{11}$ The t-value for the business density coefficient is 0.14 .

${ }^{12}$ Calculation: $(0.273 * 0.364) * 0.018=0.00179$.
} 
growth and entrepreneurship variables). The agglomeration measures are still insignificant, whereas the size variable is again positive and significant. However, when looking at employment growth in 1996-1999, the basic education variable is not only positive but also significant. Since the U.S. data only measures the extent of education in 1990 this signals that the education level is working through a relatively long lag structure. This is consistent with the result of Acs and Armington (2004) who find that the coefficient of education level on regional growth continually increases up to a 9 years lag. Another difference as compared to the estimation for 1993 - 1996 is that the population coefficient turns insignificant. When rerunning the regressions without one of the highly correlated control variables the only noticeable change is that business density turns significant.

For Sweden in the period 1996 - 1999 the relationship between entrepreneurship and regional employment growth is still positive but now also significant, as can be seen in column 4. The coefficient is slightly lower than in column 2, but when accounting for the different standard deviations of the variables an annual increase of one establishment with zero or one employee per 100 employed is now associated with an increase in employment growth of three fifths of a percentage point. As mentioned above the ICT industry had a significant impact on the Swedish economy in the latter half of the 1990’s. However, rerunning the regression and excluding the ICT industry still yields a significant estimate for entrepreneurship.

In addition to entrepreneurship business density also display a positive and significant coefficient, signalling the importance of agglomeration effects. Unlike the U.S., education is not significant, not even when the regressions are rerun using lagged education. This indicates that knowledge and employment growth is not as closely linked as in the U.S. The size variable also differs between the two countries since it is insignificant in the Swedish 
regression. One explanation might be that U.S. employment growth is not only related to small and newly formed businesses but also large-scale establishments.

In column 5 and 6, where regional employment growth and average annual entrepreneurship are measured over the full period between 1993 - 1999, the results are, as expected, a combination of the two three year periods. Entrepreneurship is still positive and significant in both countries. The only other variable that is significant in Sweden is business density, whereas in the U.S. both basic education and size are still significant, while population once again turns significantly negative. Re-running the U.S. regression without the size variable again yields a positive and significant business density coefficient, whereas rerunning the regression without business density renders the remaining variables more or less unchanged. In table 4 the same regressions as in table 3 are presented, the only difference being that human capital is now proxied by the high education variable. As can be seen, this has basically no impact on the results.

To investigate the importance of lag structure, and to control for simultaneity between regional employment growth and entrepreneurship, table 5 display the results from regressions run with control variables covering the years 1993 - 1996 on regional employment growth between 1996 - 1999. Since previous results have been unresponsive to changes in human capital variables, only regressions based on basic education will presented. The results show that the entrepreneurship variable is still positive and significant in both countries. The impact on growth is also similar as in previous estimations, indicating that the relationship between entrepreneurship and growth is tolerably lasting over a three year time span. ${ }^{13}$ In the U.S. basic education and average size of establishment is also positive and significant, which again is a source of difference compared with Sweden. Once more, the

\footnotetext{
${ }^{13}$ In the U.S. one additional firm birth per 1000 persons in a region is associated - as in regression 1, table 3 with an increase in regional employment growth by almost three fifths of a percentage point. Regression 2 implies that one extra establishment with zero or one employee per 100 employed is associated with one fourth of a percentage point increase in regional employment growth (corresponding number from regression 2, table 3, was one fifth of a percentage point).
} 
control regressions where only one of the variables with multicollinearity issue are run renders only one significant change namely that business density turns significant in the U.S.

\section{Conclusions}

This paper has investigated the effect of regional entrepreneurship, measured as firm start-ups in the U.S. and change in establishments with zero or one employee in Sweden, on regional employment growth. Regression analysis shows a strong positive association between the two variables, which is significant in 12 out of 14 regressions covering most of the 1990's. Since this connection was found in both the U.S., traditionally referred to as a high entrepreneurship country, and Sweden, with moderate entrepreneurial activity, it appears that the importance of entrepreneurship on employment growth is a general phenomenon. However, in Sweden the significance of entrepreneurship was only visible in the period covering 1996 - 1999, which was characterized by abnormal high growth rates, a strong position in a vibrant industry (ICT), but also numerous structural reforms in the period 1993 - 1996. The change in Sweden between the two periods may be an indication that policy affects the level and impact of entrepreneurship.

The results predicts that one additional firm birth per 1000 persons in the labour force is associated with an increase in regional employment growth of about three fifths of a percentage point in the U.S. In Sweden one additional establishment with zero or one employee per 100 employed is associated with an increase in regional employment growth in the range one to three fifths of a percentage point. When using lagged entrepreneurship data to prevent simultaneity between the dependent and independent variable from distorting the results, the coefficient for entrepreneurship is still positive and highly significant in both countries. It also displays similar impact as in the original regressions signifying the lasting effects of an increase in entrepreneurship. 
In the U.S. human capital, measured by the education level, is also significantly related to employment growth in most regressions, whereas no such link can be found in Sweden, signalling a less knowledge driven economy. Using high school education or university education as basis for the human capital variable only has a marginal effect on the results, which is probably due to the fact that the two measures are highly correlated. The U.S. data also display a significant relationship between regional employment growth and internal scale economies that is missing for Sweden. Once controlling for highly correlated explanatory variables both economies exhibit significant positive influences of agglomerations, measured as business density, indicating the importance of not only knowledge spillovers but also pecuniary spillovers. Variables that showed none, or weak connection with the dependent variable are business specialization and regional population.

A natural avenue for further research is to re-estimate the regressions using the same entrepreneurship variable for both countries, which will be achievable with regional distributed firm birth rates in Sweden. It would also be beneficial to go beyond the vibrant periods in the 1990's and augment the empirical analysis with data covering 1999 - 2005. 


\section{References}

Acs, Z.J., 2002, Innovations and the Growth of Cities. Cheltenham and Northampton (MA): Edward Elgar.

Acs, Z.J. and Armington, C., 2004, "Employment Growth and Entrepreneurial Activity in Cities”, Regional Studies, 38 , 911-927.

Acs, Z.J., Audretsch, D.B., Braunerhjelm, P. and Carlsson, B., 2004. “The Missing Link: The Knowledge Filter and Entrepreneurship in Economic Growth”, Working Paper No. 4358. CEPR.

Acs, Z.J., Audretsch, D.B., Braunerhjelm, P. and Carlsson, B., 2007, “The Knowledge Spillover Theory of Entrepreneurship”, CESIS Working Paper 77.

Almeida, P. and Kogut, B., 1997, "The Exploration of Technological Diversity and the Geographic Localization of Innovation”, Small Business Economics, 9, 21-31.

Arrow, K., 1962, “The Economic Implication of Learning by Doing”, Review of Economics and Statistics, 80, 155-173.

Audretsch, D.B. and Feldman, M.P., 2004, "Knowledge Spillovers and the Geography of Innovation”, in Henderson, J.V. and Thisse, J.-F. (eds.), Handbook of Regional and Urban Economics, 7, Amsterdam: Elsevier, 2713-2740.

Autant-Bernard, C., 2001, "Science and Knowledge Flows: Evidence From the French Case", Research Policy, 30, 1069-1078.

Banerjee, A.V. and Newman, A.F., 1993, “Occupational Choice and the Process of Development”, Journal of Political Economy, 101 , 274-298.

Baumol, W., 1990, “Entrepreneurship: Productive, Unproductive and Destructive”, Journal of Political Economy, 98, 893-921.

Braunerhjelm, P. and Borgman, B., 2004, "Geographical Concentration, Entrepreneurship and Regional Growth: Evidence from Regional Data in Sweden, 1975-99”, Regional Studies, 38, 929-947.

Braunerhjelm, P. and Borgman, B., 2006, “Agglomeration, Diversity and Regional Growth”, CESIS Working Paper 71.

Braunerhjelm, P. and Wiklund, J., 2006, Entreprenörskap och Tillväxt: Kunskap, Kommersialisering och Ekonomisk Politik. Örebro, Sweden: Forum för Småföretagsforskning.

Braunerhjelm, P., ”Entrepreneurship, Knowledge and Growth”, Foundations and Trends in Entrepreneurship, forthcoming.

Carree, M.A. and Thurik, A.R., 2003, "The Impact of Entrepreneurship on Economic Growth”, in Acs, Z.J. and Audretsch, D.B. (eds.), Handbook of Entrepreneurship Research. London, UK: Kluwer Academic Publishers, 437-471.

Ciccone, A., 2002, “Agglomeration Effects in Europe”, European Economic Review, 46, 213227.

Ciccone, A. and Hall, R.E., 1996, "Productivity and the Density of Economic Activity”, American Economic Review, 86, 54-70.

Cliff, A.D. and Ord, J.K., 1973, Spatial autocorrelation. London, UK: Pion.

Cooper, A., 2003, “Entrepreneurship: The Past, the Present, the Future”, in Acs, Z.J. and Audretsch, D.B. (eds.), Handbook of Entrepreneurship Research. London, UK: Kluwer Academic Publishers, 21-34.

Cullen, J.B. and Gordon, R.H., 2006, "How Do Taxes Affect Entrepreneurial Activity? A Comparison of U.S. and Swedish Law", in Braunerhjelm, P. and Wiklund, J. (eds.), Entreprenörskap och Tillväxt: Kunskap, Kommersialisering och Ekonomisk Politik, Stockholm, Sweden: Forum För Småföretagsforskning, 7193. 
Davis, S. and Henrekson, M., 1999, "Explaining Differences in the Size and Industry Distribution of Employment”, Small Business Economics, 12, 59-83.

Döring, T. and Schnellenbach, J., 2006, "What do we know about geographical knowledge spillovers and regional growth?: A survey of the literature”, Regional Studies, 40, 375-395.

Ellison, G. and Glaeser, E., 1994, "Geographic Concentration in U.S. Manufacturing Industries: A dartboard Approach”, Working Paper No. 3840. National Bureau of Economic Research. Cambridge, MA.

Feldman, M.P. and Audretsch D. B., 1999, "Innovation in Cities: Science-based Diversity, Specialization and Localized Competition”, European Economic Review, 43, 409-429.

Florida, R., 2002, The rise of the creative class. New York: Basic Books.

Glaeser, E., Kallal, H.D., Scheinkman, J.A. and Shleifer, A., 1992, "Growth in Cities”, Journal of Political Economy, 100, 1126-1152.

Hérbert, R.F. and Link, A.N., 1989, “In Search of the Meaning of Entrepreneurship”, Small Business Economics, 1, 39-49.

Iyigun, M.F. and Owen, A.L., 1999, “Entrepreneurs, Professionals, and Growth”, Journal of Economic Growth, 4, 213-232.

ITPS., 2002, Uppföljning av 1997 års Nystartade Företag - Tre År Efter Start. S2002:003. Östersund: Institutet för Tillväxtpolitiska Studier.

Jacobs, J., 1969, The Economy of Cities. New York: Random House.

Karlsson, C. and Pettersson, L., 2005, "Regional Productivity and Accessibility to Knowledge and Dense Markets”, CESIS Working Paper 32.

Karlsson, C., Gråsjö, U. and Andersson, M., 2006, "Regional Knowledge Accessibility and Regional Economic Growth”, CESIS Working Paper 66.

Keller, W., 2002, “Geographic Localization of International Technology Diffusion”, American Economic Review, 92, 120-142.

Knight, F. H., 1921, Risk, Uncertainty and Profit (Stigler, G.J., eds.). Chicago: University of Chicago Press.

Koppl, R. and Minniti, M., 2003, “Market Processes and Entrepreneurial Studies”, in Acs, Z.J. and Audretsch, D.B. (eds.), Handbook of Entrepreneurship Research.

London, UK: Kluwer Academic Publishers, 81-102.

Lucas, R., 1988, “On the Mechanics of Economic Development”, Journal of Monetary Economics, 22, 3-39.

Moen, J., 2005, “Is Mobility of Technical Personel a Source of R\&D Spillovers?”, Journal of Labour Economics, 23, 81-114.

Orlando, M.J., 2000, “On the Importance of Geographic and Technological Proximity for R\&D Spillovers: An Empirical Investigation”, Federal Reserve Bank of Kansas City Research Working Paper.

Porter, M., 1990, The Competitive Advantage of Nations. New York: Free Press.

Rauch, J.E., 1993, "Productivity Gains from Geographic Concentration of Human Capital: Evidence from the Cities”, Journal of Urban Economics, 34, 380-400.

Renolds, P.D., 1999, “Creative Destruction: Source or Symptom of Economic Growth?”, in Acs, Z.J., Carlsson, B. and Carlsson, C. (eds.), Entreprenuership, Small and Medium-Sized Enterprises and the Macroeconomy. Cambridge, UK: Cambridge University Press, 97-136.

Renolds, P.D., Camp, M. and Hay, M., 2001, Global Entrepreneurship Monitor Report. Kansas City, Missouri: E.M Kauffman Foundation.

Renolds, P.D., Bygrave, W.D. and Autio, E., 2004, Global Entrepreneurship Monitor Report. Kansas City, Missouri: E.M Kauffman Foundation. 
Rice, P., Venables, A.J. and Patacchini, E., 2006, "Spatial determinants of productivity: Analysis for the regions of Great Britain”, Regional Science and Urban Economics, 36, 727-752.

Romer, P., 1986, “Increasing Returns and Economic Growth”, American Economic Review, 94, 1002-1037.

Romer, P., 1990, “Endogenous Technical Change”, Journal of Political Economy, 98, 71-102. Sarasvathy, S.D., Dew, N., Velamuri, S.R. and Venkataraman, S., 2003, “Three Views of Entrepreneurial Opportunity”, in Acs, Z.J. and Audretsch, D.B. (eds.), Handbook of Entrepreneurship Research. London, UK: Kluwer Academic Publishers, 141160.

Schumpeter, J., 1911 [1934], The Theory of Economic Development, Cambridge, MA: Harvard University Press.

Shane, S.A., 2000, "Prior Knowledge and the Discovery of Entrepreneurial Opportunities”, Organization Science, 11, 448-469.

Simon, C.J. and Nardinelli, C., 2002, "Human Capital and the Rise of American Cities, 1900 - 1990”, Regional Science and Urban Economics, 32, 59-96.

Söderström, H., Braunerhjelm, P, Friberg, R., Norman, V. and Sölvell, R., 2001, Kluster.se, Stockholm, Sweden: SNS Förlag.

Solow, R., 1956, “A Contribution to Theory of Economic Growth”, Quarterly Journal of Economics, 70, 65-94.

Tolbert, C.M. and Sizer, M., 1996, U.S. Commuting Zones and Labor Market Areas: A 1990 Update. Washington, DC: Rural Economy Division, Economic Research Service, US Department of Agriculture.

Von Hippel, E., 1994, "Sticky Information and the Locus of Problem Solving: implications for Innovation”, Management Science, 40, 429-439.

White, H., 1980, “A Heteroscedasticity-Consistent Covariance Matrix Estimator and a Direct Test for Heteroscedasticity”, Econometrica, 48, 817-838.

Wolfe, D.A. and Gertler, M.S., 2006, "Local Antecedents and Trigger Events: Policy Implications of Path Dependence for Cluster Formation”, in Braunerhjelm, P. and Feldman, M.P. (eds.), Cluster Genesis: Technology-Based Industrial Development. New York: Oxford University Press. 
Figure 1. Development of GDP in the U.S. and Sweden between 1980 and 2000, at the price level and PPPs of 1995.

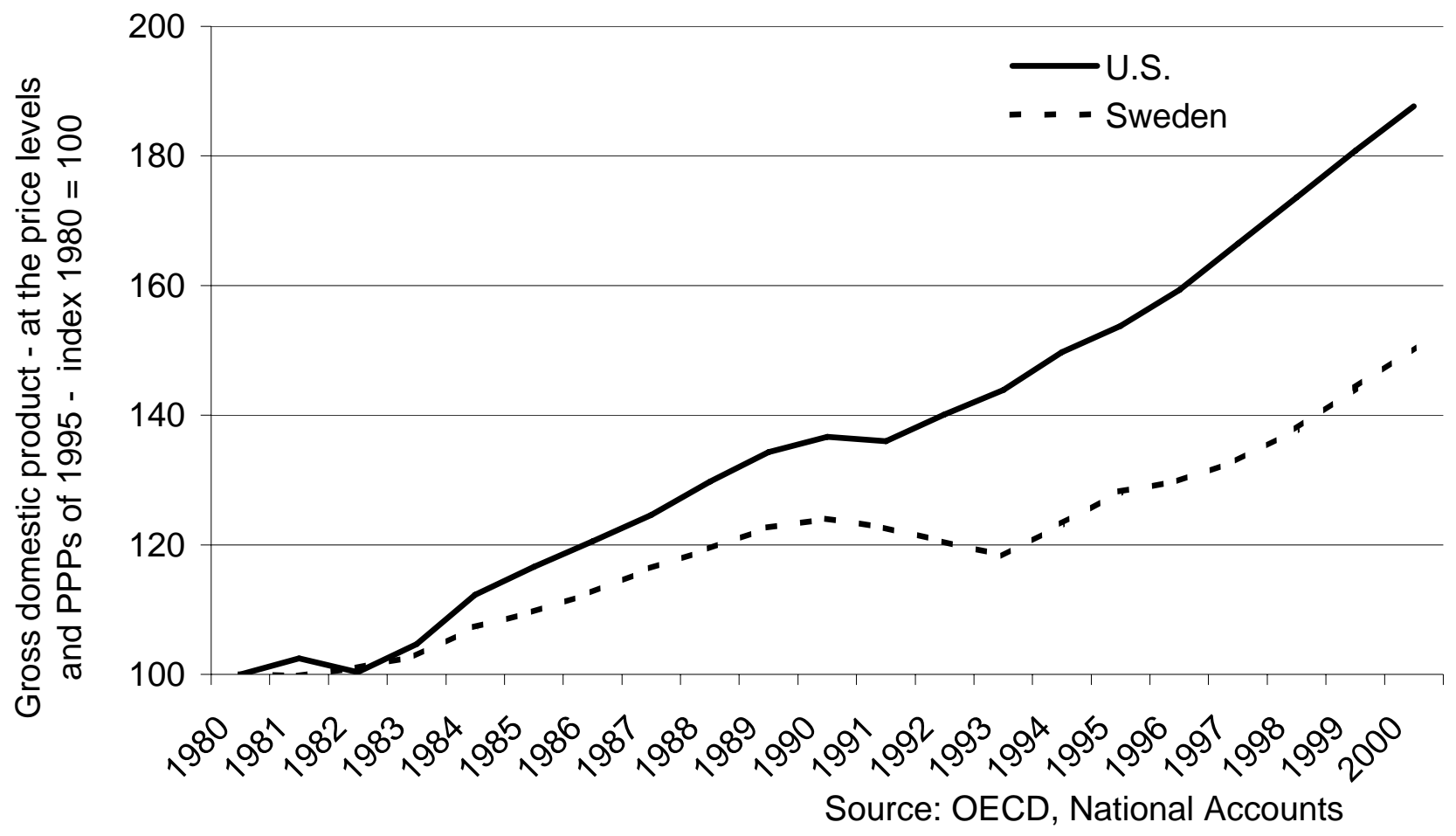

Figure 2. Development of unemployment rates in the U.S. and Sweden between 1980 and 2000, as percentage of total labour force.

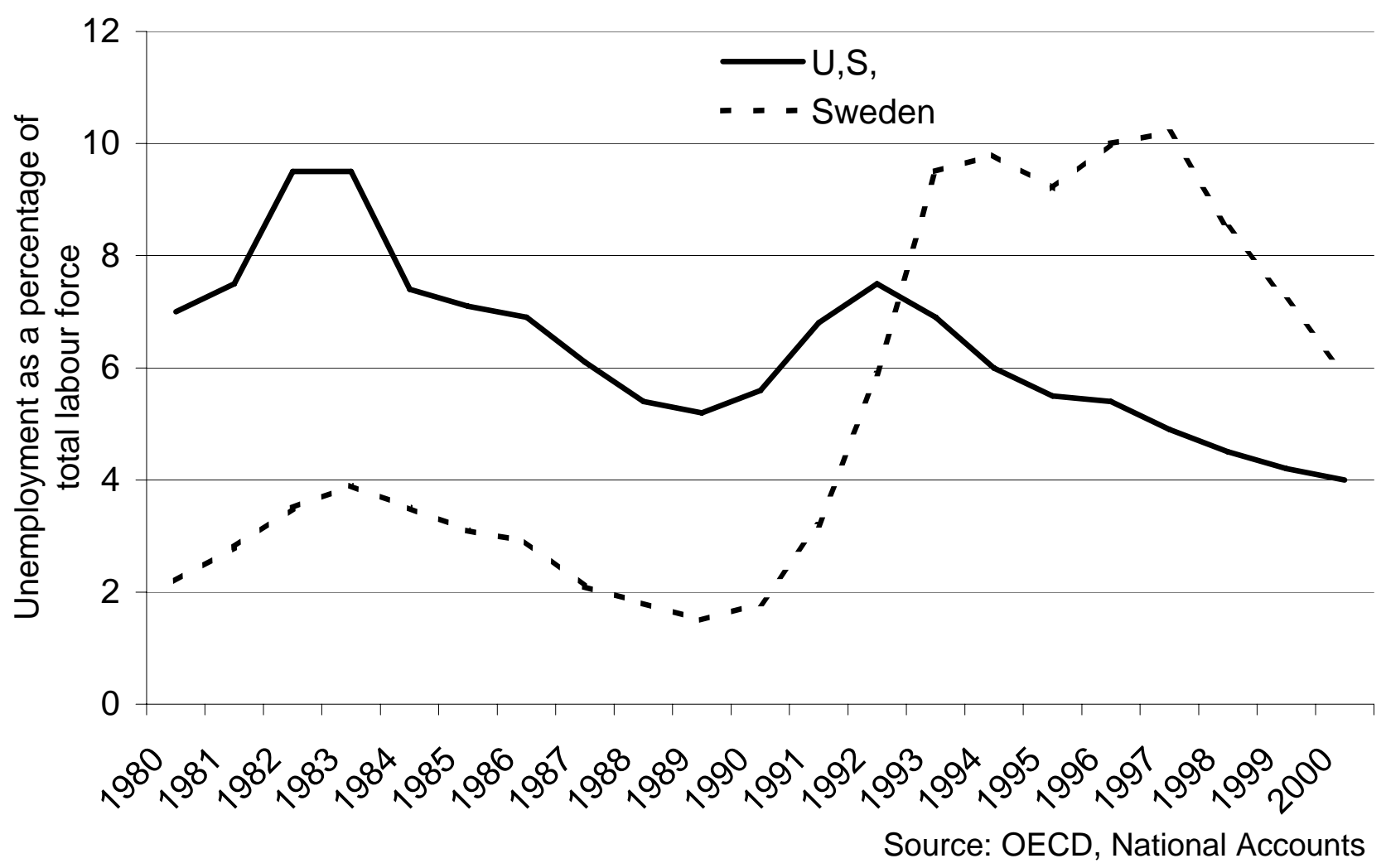


Figure 3. Correlation between entrepreneurship and regional employment growth in the U.S. between 1993 - 1996.

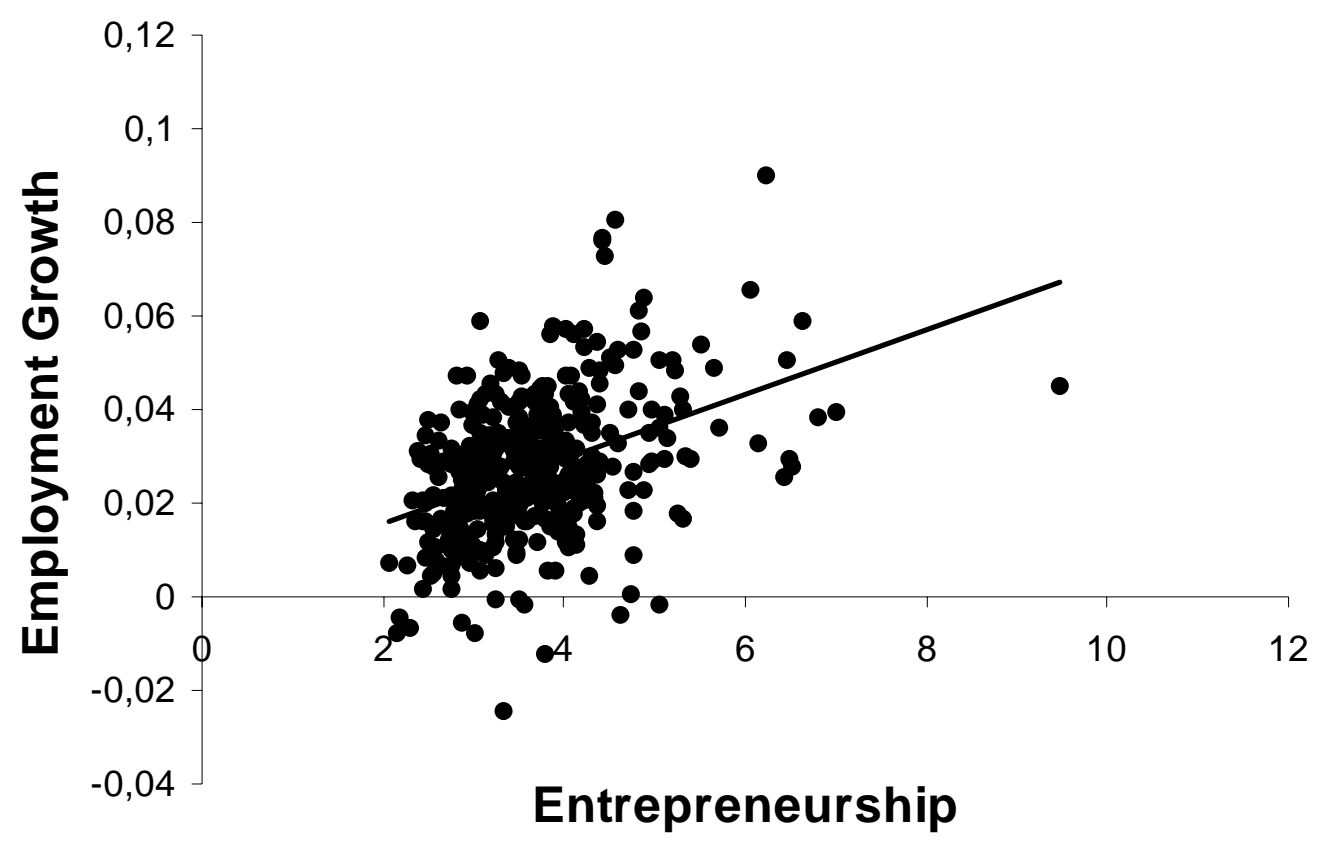

Source: 1989 - 1996 LEEM File, US Bureau of the Census

Figure 4. Correlation between entrepreneurship and regional employment growth in the U.S. between 1996 - 1999.

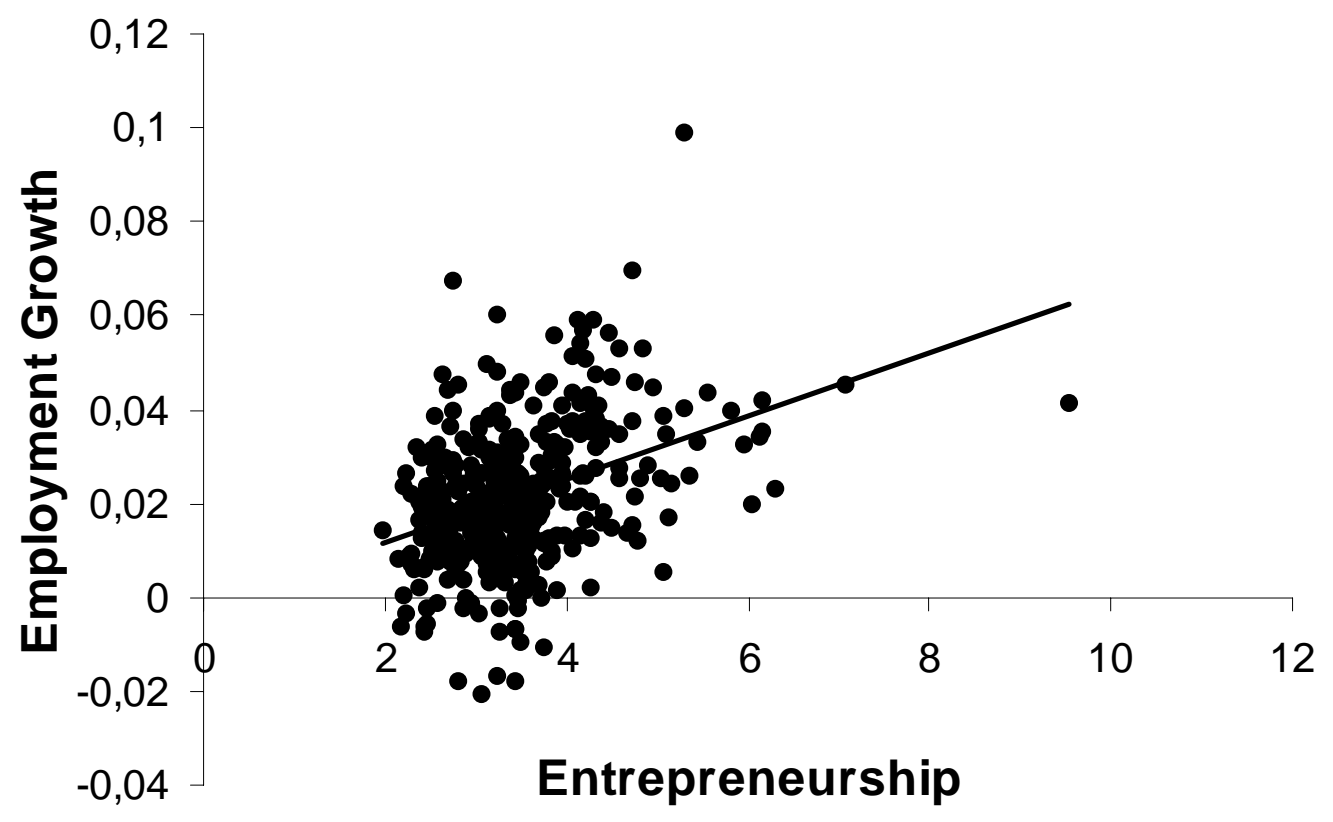

Source: 1989 - 1996 LEEM File, US Bureau of the Census 
Figure 5. Correlation between entrepreneurship and regional employment growth in Sweden between 1993 - 1996.

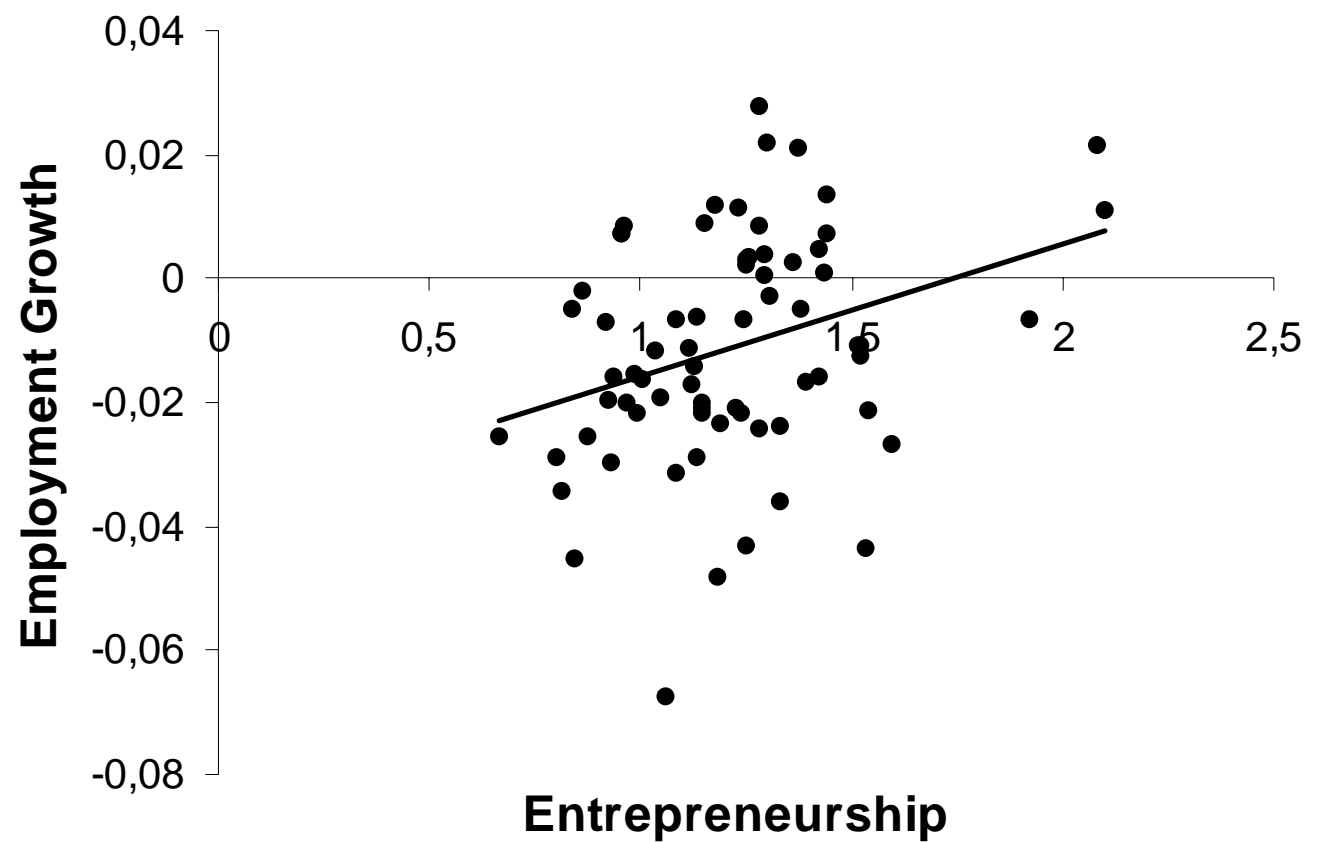

Source: SCB

Figure 6. Correlation between entrepreneurship and regional employment growth in Sweden between 1996 - 1999.

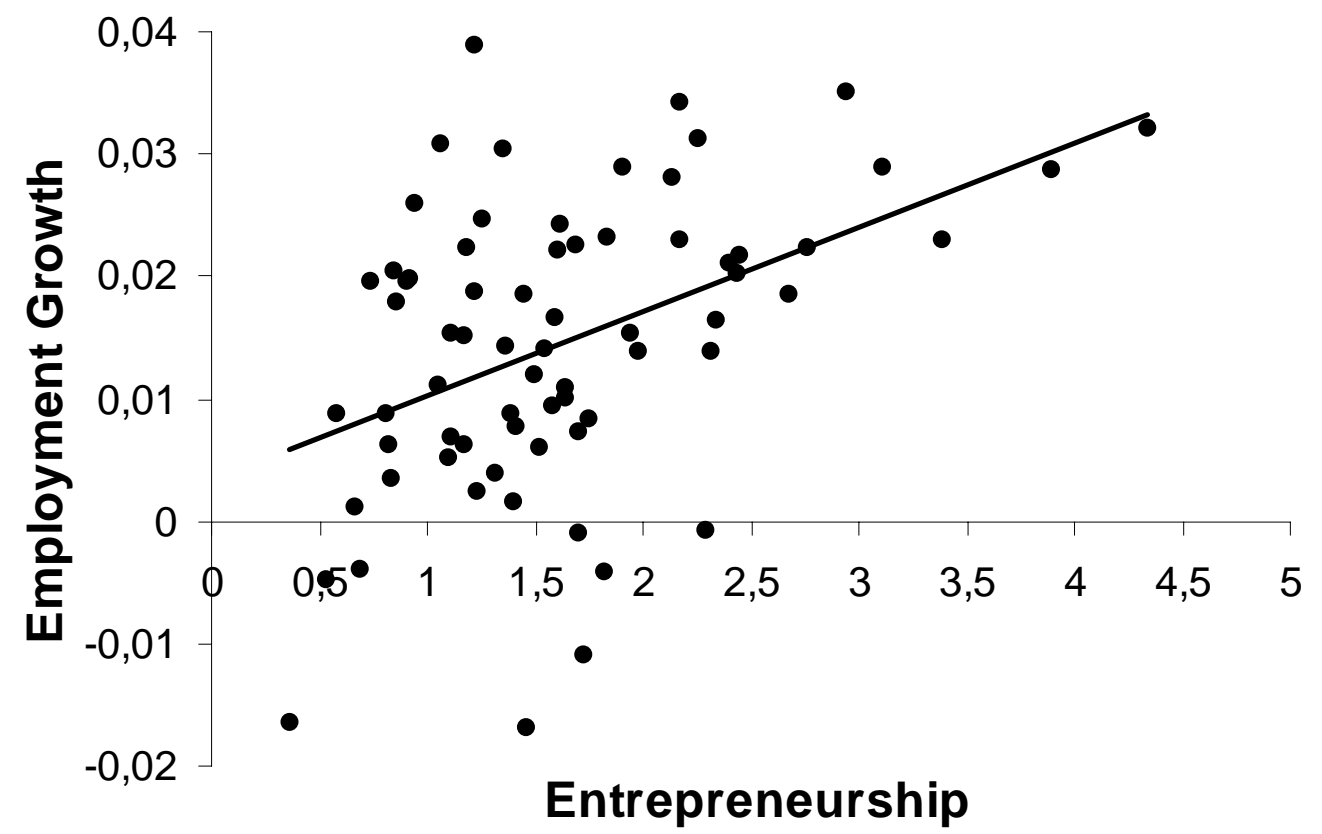

Source: SCB 
Table 1. The compounded average annual employment growth rate between 1993 and 1999 for the 10 American and Swedish regions with highest and lowest rates.

\begin{tabular}{|c|c|c|c|c|c|c|c|c|}
\hline \multirow[b]{2}{*}{ Hig } & \multicolumn{4}{|l|}{ U.S. } & \multicolumn{4}{|l|}{ Sweden } \\
\hline & Growth Regions & $\begin{array}{r}(1) \\
\text { Employ- }^{(1)} \text { ment }^{1}\end{array}$ & $\begin{array}{r}\text { (2) } \\
\text { Popul- } \\
\text { ation }^{2}\end{array}$ & $(1)-(2)^{3}$ & & $\begin{array}{r}(1) \\
\text { Employ- }^{-} \\
\text {ment }^{1}\end{array}$ & $\begin{array}{r}(2) \\
\text { Popul- } \\
\text { ation }^{2}\end{array}$ & $(1)-(2)^{3}$ \\
\hline 1 & Las Vegas & 7.5 & 5.2 & 2.4 & Enkoping & 6.1 & 0.1 & 6.1 \\
\hline 2 & Provo & 6.7 & 3.1 & 3.6 & Skelleftea & 5.1 & -0.8 & 5.9 \\
\hline 3 & St. George & 6.7 & 3.8 & 2.9 & Gothenburg & 4.8 & 0.9 & 3.9 \\
\hline 4 & Austin & 6.6 & 3.5 & 3.1 & Saffle & 4.4 & -1.0 & 5.4 \\
\hline 5 & Sarasota & 6.5 & 1.3 & 5.2 & Visby & 3.9 & 0.2 & 3.7 \\
\hline 6 & Phoenix & 6.4 & 3.5 & 2.9 & Karlskrona & 3.7 & 0.4 & 3.3 \\
\hline 7 & Colorado Springs & 5.4 & 2.6 & 2.8 & Varnamo & 3.7 & 0.4 & 3.3 \\
\hline 8 & Orlando & 5.3 & 2.4 & 2.9 & Norrtalje & 3.4 & 1.0 & 2.4 \\
\hline 9 & Flagstaff & 5.3 & 2.6 & 2.7 & Mora & 3.2 & -0.6 & 3.7 \\
\hline 10 & Atlanta & 5.2 & 3.0 & 2.2 & Arvika & 2.9 & -0.6 & 3.5 \\
\hline \multicolumn{9}{|c|}{ Low Growth Regions } \\
\hline 1 & Honolulu & -0.8 & 0.2 & -1.0 & Ornskoldsvik & -5.5 & -0.8 & -4.7 \\
\hline 2 & Binghamton & -0.6 & -0.8 & 0.3 & Avesta & -3.8 & -0.9 & -2.8 \\
\hline 3 & Olney & -0.4 & -0.4 & -0.0 & Koping & -3.3 & -1.0 & -2.3 \\
\hline 4 & Greenville & -0.4 & -0.8 & 0.4 & Ludvika & -3.1 & -1.1 & -2.0 \\
\hline 5 & Steubenville & -0.4 & -0.9 & 0.5 & Norrkoping & -2.6 & 0.1 & -2.7 \\
\hline 6 & Amsterdam & -0.2 & -0.5 & 0.4 & Harnosand & -2.4 & -1.1 & -1.4 \\
\hline 7 & Pikeville & 0.1 & -0.3 & 0.4 & Nykoping & -2.4 & -0.2 & -2.2 \\
\hline 8 & Watertown & 0.1 & -0.4 & 0.6 & Lindesberg & -2.2 & -1.0 & -1.2 \\
\hline 9 & Big Spring & 0.2 & -0.3 & 0.5 & Lulea & -2.1 & -0.2 & -1.8 \\
\hline 10 & Woodward & 0.3 & -0.3 & 0.6 & Vasteras & -2.0 & -0.0 & -2.0 \\
\hline
\end{tabular}

${ }^{1}$ Column 1 refers to annual compounded employment growth rates between the years $1993-1999$.

${ }^{2}$ Column 2 refers to annual compounded population growth rates between the years $1993-1999$.

${ }^{3}$ Column 3 refers to the values in column 1, subtracted with the values in column 2.

Source: U.S. data: 1989-99 LEEM file, US Bureau of the Census, US Bureau of Labor Statistics. Swedish data:

Statistics Sweden (SCB). 
Table 2. The average level of entrepreneurship between 1993 - 1999 for the 10 American and Swedish regions with highest and lowest entrepreneurial activity, and their associated compounded average annual employment growth rate.

\begin{tabular}{|c|c|c|c|c|c|c|}
\hline \multicolumn{2}{|r|}{ U.S. } & & & \multicolumn{3}{|l|}{ Sweden } \\
\hline \multicolumn{2}{|c|}{$\begin{array}{l}\text { High Entrepreneurship } \\
\text { Regions }\end{array}$} & $\begin{array}{l}\text { Entrepre- } \\
\text { neurship }^{1}\end{array}$ & $\begin{array}{l}\text { Employ- } \\
\text { ment }^{2}\end{array}$ & & $\begin{array}{l}\text { Entrepre- } \\
\text { neurship }\end{array}$ & $\begin{array}{r}\text { Employ- } \\
\text { ment }^{2}\end{array}$ \\
\hline 1 & Glenwood & 9.5 & 4.3 & Arvika & 2.8 & 2.9 \\
\hline 2 & Cape Coral & 7.0 & 4.2 & Mora & 2.7 & 3.2 \\
\hline 3 & West Palm Beach & 6.5 & 3.7 & Skelleftea & 2.4 & 5.1 \\
\hline 4 & Port Angeles & 6.4 & 2.4 & Lycksele & 2.3 & 0.6 \\
\hline 5 & Grand Junction & 6.4 & 4.6 & Saffle & 2.1 & 4.4 \\
\hline 6 & Kalispell & 6.3 & 3.5 & Ostersund & 2.1 & 0.6 \\
\hline 7 & Miami & 6.3 & 2.5 & Norrtalje & 1.9 & 3.4 \\
\hline 8 & La Grande & 6.2 & 4.2 & Ljungby & 1.9 & 2.5 \\
\hline 9 & Flagstaff & 5.9 & 5.3 & Tranas & 1.8 & 0.9 \\
\hline 10 & St. George & 5.9 & 6.7 & Vaxjo & 1.8 & 2.8 \\
\hline \multicolumn{7}{|c|}{$\begin{array}{l}\text { Low Entrepreneurship } \\
\text { Regions }\end{array}$} \\
\hline 1 & Elmira & 2.0 & 1.1 & Fagersta & 0.7 & -0.9 \\
\hline 2 & Binghamton & 2.2 & -0.6 & Kristinehamn & 0.7 & -1.7 \\
\hline 3 & Oneonta & 2.2 & 0.3 & Vasteras & 0.8 & -2.0 \\
\hline 4 & Sunbury & 2.3 & 1.2 & Karlshamn & 0.9 & 0.2 \\
\hline 5 & Sheboygan & 2.3 & 2.4 & Skovde & 0.9 & -1.5 \\
\hline 6 & Lorain & 2.3 & 1.8 & Kristianstad & 0.9 & -0.2 \\
\hline 7 & Findlay & 2.3 & 2.7 & Gavle & 0.9 & -1.4 \\
\hline 8 & Syracuse & 2.4 & 0.5 & Ludvika & 0.9 & -3.1 \\
\hline 9 & Harrisburg & 2.4 & 1.6 & Eskilstuna & 0.9 & -1.6 \\
\hline 10 & Richmond & 2.4 & 2.1 & Helsingborg & 0.9 & -2.0 \\
\hline
\end{tabular}

${ }^{1}$ Column 1 refers to average annual entrepreneurship between $1993-1999$. U.S. data is scaled by 1000 individuals in the labour force whereas Swedish data is scaled by 100 in the employment.

${ }^{2}$ Column 2 refers to annual compounded employment growth rates between the years $1993-1999$.

Source: U.S. data: 1989-99 LEEM file, US Bureau of the Census, US Bureau of Labor Statistics. Swedish data: Statistics Sweden (SCB). 
Table 3. Regression results for U.S. and Sweden, years 1993 - 1999, using basic education as human capital variable. Dependent variable is regional employment growth.

\begin{tabular}{|c|c|c|c|c|c|c|}
\hline & $\begin{array}{c}(1) \\
\text { USA } \\
\mathrm{t}=93 ; \mathrm{i}=3\end{array}$ & $\begin{array}{c}(2) \\
\mathrm{SWE} \\
\mathrm{t}=93 ; \mathrm{i}=3\end{array}$ & $\begin{array}{c}(3) \\
\text { USA } \\
\mathrm{t}=96 ; \mathrm{i}=3\end{array}$ & $\begin{array}{c}(4) \\
\text { SWE } \\
\mathrm{t}=96 ; \mathrm{i}=3\end{array}$ & $\begin{array}{c}(5) \\
\text { USA } \\
\mathrm{t}=93 ; \mathrm{i}=6\end{array}$ & $\begin{array}{c}(6) \\
\text { SWE } \\
\mathrm{t}=93 ; \mathrm{i}=6\end{array}$ \\
\hline Entr & $\begin{array}{l}0.442 * * * \\
(7.73)\end{array}$ & $\begin{array}{l}0.364 \\
(1.10)\end{array}$ & $\begin{array}{l}0.378 * * * \\
(6.69)\end{array}$ & $\begin{array}{l}0.345 * * * \\
(5.53)\end{array}$ & $\begin{array}{l}0.572 * * * \\
(7.90)\end{array}$ & $\begin{array}{l}0.639 * * * \\
(4.93)\end{array}$ \\
\hline Specialization & $\begin{array}{l}0.009 \\
(0.26)\end{array}$ & $\begin{array}{l}-0.128 \\
(-0.41)\end{array}$ & $\begin{array}{l}0.004 \\
(0.12)\end{array}$ & $\begin{array}{l}-0.087 \\
(-0.61)\end{array}$ & $\begin{array}{l}0.026 \\
(0.59)\end{array}$ & $\begin{array}{l}-0.194 \\
(-0.65)\end{array}$ \\
\hline Businessdensity & $\begin{array}{l}-0.180 * * \\
(-2.59)\end{array}$ & $\begin{array}{l}0.061 \\
(0.45)\end{array}$ & $\begin{array}{l}0.061 \\
(0.92)\end{array}$ & $\begin{array}{l}0.260 * * * \\
(2.70)\end{array}$ & $\begin{array}{l}-0.082 \\
(-1.05)\end{array}$ & $\begin{array}{l}0.377 * * * \\
(2.88)\end{array}$ \\
\hline Basiced & $\begin{array}{l}0.055 \\
(1.23)\end{array}$ & $\begin{array}{l}-0.052 \\
(-0.27)\end{array}$ & $\begin{array}{l}0.178^{* * *} \\
(3.73)\end{array}$ & $\begin{array}{l}0.140 \\
(1.25)\end{array}$ & $\begin{array}{l}0.171^{* * * *} \\
(3.73)\end{array}$ & $\begin{array}{l}0.063 \\
(0.38)\end{array}$ \\
\hline Size & $\begin{array}{l}0.331 * * * \\
(4.99)\end{array}$ & $\begin{array}{l}-0.316 \\
(-1.03)\end{array}$ & $\begin{array}{l}0.153^{* *} \\
(2.33)\end{array}$ & $\begin{array}{l}-0.158 \\
(-0.88)\end{array}$ & $\begin{array}{l}0.339 * * * \\
(4.28)\end{array}$ & $\begin{array}{l}-0.221 \\
(-0.80)\end{array}$ \\
\hline Population & $\begin{array}{l}-0.105^{* * *} \\
(-3.36)\end{array}$ & $\begin{array}{l}0.180 \\
(1.22)\end{array}$ & $\begin{array}{l}0.007 \\
(0.18)\end{array}$ & $\begin{array}{l}0.025 \\
(0.37)\end{array}$ & $\begin{array}{l}-0.076 * * \\
(-1.98)\end{array}$ & $\begin{array}{l}0.115 \\
(1.00)\end{array}$ \\
\hline Intercept & $\begin{array}{l}0.103^{* * *} \\
(2.73)\end{array}$ & $\begin{array}{l}-0.552 \\
(-1.65)\end{array}$ & $\begin{array}{l}-0.187 * * * \\
(-4.63)\end{array}$ & $\begin{array}{l}0.496 * * * \\
(5.51)\end{array}$ & $\begin{array}{l}0.030 \\
(0.70)\end{array}$ & $\begin{array}{l}0.284 \\
(0.84)\end{array}$ \\
\hline $\mathrm{R}^{2}$ & 0.253 & 0.143 & 0.245 & 0.320 & 0.321 & 0.371 \\
\hline
\end{tabular}

Note: t-statistics in parentheses. *, ** and *** denote the significance at the 10, 5 and 1 percent level, respectively.

Table 4. Regression results for U.S. and Sweden, years 1993 - 1999, using high education as human capital variable. Dependent variable is regional employment growth.

\begin{tabular}{|c|c|c|c|c|c|c|}
\hline & $\begin{array}{c}(1) \\
\text { USA } \\
\mathrm{t}=93 ; \mathrm{i}=3\end{array}$ & $\begin{array}{c}(2) \\
\text { SWE } \\
\mathrm{t}=93 ; \mathrm{i}=3\end{array}$ & $\begin{array}{c}(3) \\
\text { USA } \\
\mathrm{t}=96 ; \mathrm{i}=3\end{array}$ & $\begin{array}{c}(4) \\
\text { SWE } \\
t=96 ; i=3\end{array}$ & $\begin{array}{c}\text { (5) } \\
\text { USA } \\
\mathrm{t}=93 ; \mathrm{i}=6\end{array}$ & $\begin{array}{c}(6) \\
\text { SWE } \\
\mathrm{t}=93 ; \mathrm{i}=6\end{array}$ \\
\hline Entr & $\begin{array}{l}0.445 * * * \\
(7.61)\end{array}$ & $\begin{array}{l}0.246 \\
(0.73)\end{array}$ & $\begin{array}{l}0.338 * * * \\
(5.57)\end{array}$ & $\begin{array}{l}0.348 * * * \\
(5.56)\end{array}$ & $\begin{array}{l}0.544 * * * \\
(7.12)\end{array}$ & $\begin{array}{l}0.624 * * * \\
(4.73)\end{array}$ \\
\hline Specialization & $\begin{array}{l}0.010 \\
(0.31)\end{array}$ & $\begin{array}{l}-0.115 \\
(-0.36)\end{array}$ & $\begin{array}{l}0.014 \\
(0.40)\end{array}$ & $\begin{array}{l}-0.124 \\
(-0.84)\end{array}$ & $\begin{array}{l}0.027 \\
(0.63)\end{array}$ & $\begin{array}{l}-0.202 \\
(-0.65)\end{array}$ \\
\hline Businessdensity & $\begin{array}{l}-0.182 * * * \\
(-2.64)\end{array}$ & $\begin{array}{l}0.071 \\
(0.65)\end{array}$ & $\begin{array}{l}0.032 \\
(0.46)\end{array}$ & $\begin{array}{l}0.199 * * \\
(2.53)\end{array}$ & $\begin{array}{l}-0.104 \\
(-1.31)\end{array}$ & $\begin{array}{l}0.333^{* * *} \\
(2.98)\end{array}$ \\
\hline Highed & $\begin{array}{l}0.022 \\
(0.44)\end{array}$ & $\begin{array}{l}0.135 \\
(0.73)\end{array}$ & $\begin{array}{l}0.203^{* * * *} \\
(4.23)\end{array}$ & $\begin{array}{l}0.178 \\
(1.57)\end{array}$ & $\begin{array}{l}0.167^{* * * *} \\
(2.98)\end{array}$ & $\begin{array}{l}0.183 \\
(1.23)\end{array}$ \\
\hline Size & $\begin{array}{l}0.331 * * * \\
(4.90)\end{array}$ & $\begin{array}{l}-0.397 \\
(-1.25)\end{array}$ & $\begin{array}{l}0.132^{*} \\
(1.91)\end{array}$ & $\begin{array}{l}-0.178 \\
(-0.98)\end{array}$ & $\begin{array}{l}0.319 * * * \\
(3.83)\end{array}$ & $\begin{array}{l}-0.251 \\
(-0.88)\end{array}$ \\
\hline Population & $\begin{array}{l}-0.103 * * * \\
(-2.92)\end{array}$ & $\begin{array}{l}0.123 \\
(0.92)\end{array}$ & $\begin{array}{l}-0.023 \\
(-0.59)\end{array}$ & $\begin{array}{l}0.017 \\
(0.30)\end{array}$ & $\begin{array}{l}-0.097 * * \\
(-2.34)\end{array}$ & $\begin{array}{l}0.079 \\
(0.80)\end{array}$ \\
\hline Intercept & $\begin{array}{l}0.102 \\
(2.71)\end{array}$ & $\begin{array}{l}-0.420 * \\
(-1.68)\end{array}$ & $\begin{array}{l}-0.190 \\
(-4.63)\end{array}$ & $\begin{array}{l}0.499 \\
(5.59)\end{array}$ & $\begin{array}{l}0.027 \\
(0.63)\end{array}$ & $\begin{array}{l}0.316 \\
(1.20)\end{array}$ \\
\hline $\begin{array}{l}\mathrm{R}^{2} \\
\text { Obs }\end{array}$ & $\begin{array}{l}0.243 \\
394\end{array}$ & $\begin{array}{l}0.148 \\
70\end{array}$ & $\begin{array}{l}0.243 \\
394\end{array}$ & $\begin{array}{l}0.336 \\
70\end{array}$ & $\begin{array}{l}0.312 \\
394\end{array}$ & $\begin{array}{l}0.380 \\
70\end{array}$ \\
\hline
\end{tabular}

Note: t-statistics in parentheses. ${ }^{*}, * *$ and $* * *$ denote the significance at the 10,5 and 1 percent level, respectively. 
Table 5. Regression results for U.S. and Sweden, dependent variable covering years 1996 - 1999, independent variables covering year 1993 - 1996. Dependent variable is regional employment growth.

\begin{tabular}{|l|ll|}
\hline & \multicolumn{1}{|c|}{$(1)$} & \multicolumn{1}{c|}{$(2)$} \\
& \multicolumn{1}{|c|}{ USA } & \multicolumn{1}{c|}{ SWE } \\
\hline Entr & $0.413^{* * *}$ & $0.851^{* * *}$ \\
& $(6.68)$ & $(2.68)$ \\
Specialization & 0.022 & 0.130 \\
Businessdensity & $(0.41)$ & $(0.46)$ \\
& 0.070 & -0.172 \\
Education & $(0.89)$ & $(-1.21)$ \\
& $0.193^{* * *}$ & -0.020 \\
Size & $(3.46)$ & $(-0.09)$ \\
& $0.190^{* *}$ & 0.106 \\
Population & $(2.45)$ & $(0.35)$ \\
Intercept & 0.006 & 0.155 \\
& $(0.14)$ & $(1.28)$ \\
\hline $\mathrm{R}^{2}$ & -0.015 & 0.165 \\
Obs & $(-0.36)$ & $(0.53)$ \\
\hline
\end{tabular}

Note: t-statistics in parentheses. ${ }^{*}, * *$ and ${ }^{* * *}$ denote the significance at the 10,5 and 1 percent level, respectively. 


\section{Appendix}

Table A1a. U.S. summary statistics and expected signs.

\begin{tabular}{|c|c|c|c|c|c|c|}
\hline & Definitions & Min & Mean & Max & $\begin{array}{r}\text { Std. } \\
\text { Dev. }\end{array}$ & $\begin{array}{l}\text { Exp. } \\
\text { Sign }\end{array}$ \\
\hline \multirow[t]{4}{*}{ EmploymentGrowth } & $\left(\mathrm{Empl}_{\mathrm{r},(\mathrm{t}+\mathrm{i})} / \mathrm{Empl}_{\mathrm{r}, \mathrm{t}}\right)^{1 / \mathrm{i}}-1$ & & & & & \\
\hline & $\mathrm{t}=1993, \mathrm{i}=3$ & -0.024 & 0.027 & 0.090 & 0.015 & \\
\hline & $t=1996, i=3$ & -0.021 & 0.021 & 0.099 & 0.015 & \\
\hline & $\mathrm{t}=1993, \mathrm{i}=6$ & -0.008 & 0.024 & 0.075 & 0.012 & \\
\hline \multirow[t]{4}{*}{ Entrepreneurship } & \multicolumn{5}{|c|}{ Average Yearly Firm Formation / Lforce $_{\mathrm{r}, \mathrm{t}} * 1000$} & + \\
\hline & $\mathrm{t}=1993, \mathrm{i}=3$ & 2.059 & 3.651 & 9.471 & 0.893 & \\
\hline & $t=1996, i=3$ & 1.970 & 3.450 & 9.543 & 0.849 & \\
\hline & $\mathrm{t}=1993, \mathrm{i}=6$ & 2.015 & 3.551 & 9.508 & 0.863 & \\
\hline \multirow[t]{3}{*}{ Specialization } & $\left(\mathrm{Est}_{\mathrm{r}, \mathrm{t}} / \mathrm{Pop}_{\mathrm{r}, \mathrm{t}}\right) /\left(\mathrm{Est}_{\mathrm{t}} / \mathrm{Pop}_{\mathrm{t}}\right)$ & & & & & + \\
\hline & $\mathrm{t}=1993$ & 0.613 & 0.979 & 1.433 & 0.151 & \\
\hline & $\mathrm{t}=1996$ & 0.514 & 0.976 & 2.048 & 0.163 & \\
\hline \multirow[t]{3}{*}{ Business Density } & Ln(establishments $\mathrm{r}, \mathrm{t}_{\mathrm{t}} /$ area $\left._{\mathrm{r}}\right)$ & & & & & + \\
\hline & $t=1993$ & 3.897 & 8.600 & 12.805 & 1.166 & \\
\hline & $\mathrm{t}=1996$ & 3.954 & 8.645 & 12.846 & 1.164 & \\
\hline \multirow[t]{2}{*}{ Basic Education } & \multicolumn{5}{|c|}{ Share of adults over 25 years with a high school degree 1990} & + \\
\hline & $\mathrm{t}=1990$ & 0.459 & 0.721 & 0.883 & 0.080 & \\
\hline \multirow[t]{2}{*}{ High Education } & \multicolumn{5}{|c|}{ Share of adults over 25 years with a university degree 1990} & + \\
\hline & $\mathrm{t}=1990$ & 0.068 & 0.159 & 0.320 & 0.050 & \\
\hline \multirow[t]{3}{*}{ Size } & Employment $_{\mathrm{r}, \mathrm{t}} / \mathrm{establishment}_{\mathrm{r}, \mathrm{t}}$ & & & & & $+/-$ \\
\hline & $t=1993$ & 8.154 & 15.044 & 21.276 & 2.829 & \\
\hline & $t=1996$ & 8.284 & 15.588 & 22.724 & 2.896 & \\
\hline \multirow[t]{3}{*}{ Population } & Population $_{\mathrm{r}, \mathrm{t}}$ & & & & & $+/-$ \\
\hline & $t=1993$ & $101^{\prime}$ & $651^{\prime}$ & 15149’ & $1264^{\prime}$ & \\
\hline & $t=1996$ & $103^{\prime}$ & 669' & 15384' & 1288' & \\
\hline
\end{tabular}

Source: 1989-99 LEEM file, US Bureau of the Census, US Bureau of Labor Statistics. 
Table A1b. Swedish summary statistics and expected signs.

\begin{tabular}{|c|c|c|c|c|c|c|}
\hline & Definitions & Min & Mean & Max & Std. Dev. & $\begin{array}{l}\text { Exp. } \\
\text { Sign }\end{array}$ \\
\hline \multirow[t]{4}{*}{ EmploymentGrowth } & $\left(\mathrm{Empl}_{\mathrm{r},(\mathrm{t}+\mathrm{i})} / \mathrm{Empl}_{\mathrm{r}, \mathrm{t}}\right)^{1 / \mathrm{i}}-1$ & & & & & \\
\hline & $t=1993, i=3$ & -0.067 & -0.011 & 0.028 & 0.018 & \\
\hline & $\mathrm{t}=1996, \mathrm{i}=3$ & -0.016 & 0.015 & 0.039 & 0.012 & \\
\hline & $\mathrm{t}=1993, \mathrm{i}=6$ & -0.055 & 0.003 & 0.061 & 0.023 & \\
\hline \multirow[t]{4}{*}{ Entrepreneurship } & $\begin{array}{l}\left\{\left[(\text { Est with } 0 \text { or } 1 \text { employee })_{\mathrm{r},(\mathrm{t}+\mathrm{i})}-(\mathrm{Es}\right.\right. \\
/(\mathrm{Empl})_{\mathrm{r}, \mathrm{t}} * 100\end{array}$ & with 0 & r 1 empl & yee $\left.\left.)_{r, t}\right] / i\right\}$ & & + \\
\hline & $t=1993, i=3$ & 0.662 & 1.213 & 2.100 & 0.273 & \\
\hline & $t=1996, i=3$ & 0.357 & 1.625 & 4.336 & 0.773 & \\
\hline & $\mathrm{t}=1993, \mathrm{i}=6$ & 0.660 & 1.394 & 2.803 & 0.439 & \\
\hline \multirow[t]{3}{*}{ Specialization } & $\left(\mathrm{Est}_{\mathrm{r}, \mathrm{t}} / \mathrm{Pop}_{\mathrm{r}, \mathrm{t}}\right) /\left(\mathrm{Est}_{\mathrm{t}} / \mathrm{Pop}_{\mathrm{t}}\right)$ & & & & & + \\
\hline & $t=1993$ & 0.725 & 0.997 & 1.334 & 0.120 & \\
\hline & $t=1996$ & 0.714 & 0.984 & 1.314 & 0.122 & \\
\hline \multirow[t]{3}{*}{ Business Density } & Ln(establishments $\left.{ }_{\mathrm{r}, \mathrm{t}} / \mathrm{area}_{\mathrm{r}}\right)$ & & & & & + \\
\hline & $t=1993$ & -2.744 & 0.327 & 3.100 & 1.079 & \\
\hline & $\mathrm{t}=1996$ & -2.711 & 0.372 & 3.226 & 1.099 & \\
\hline \multirow[t]{3}{*}{ Basic Education } & \multicolumn{5}{|c|}{ Share of adults over 25 years with a high school degree } & + \\
\hline & $t=1993$ & 0.614 & 0.709 & 0.806 & 0.041 & \\
\hline & $t=1996$ & 0.655 & 0.750 & 0.845 & 0.042 & \\
\hline \multirow[t]{3}{*}{ High Education } & \multicolumn{5}{|c|}{ Share of adults over 25 years with a university degree } & + \\
\hline & $t=1993$ & 0.059 & 0.094 & 0.202 & 0.026 & \\
\hline & $t=1996$ & 0.060 & 0.102 & 0.219 & 0.029 & \\
\hline \multirow[t]{3}{*}{ Size } & Employment $_{r, t} /$ establishment $_{r, t}$ & & & & & $+/-$ \\
\hline & $t=1993$ & 4.153 & 6.543 & 8.914 & 1.058 & \\
\hline & $t=1996$ & 3.671 & 6.037 & 7.880 & 0.936 & \\
\hline \multirow[t]{3}{*}{ Population } & Population $_{\mathrm{r}, \mathrm{t}}$ & & & & & $+/-$ \\
\hline & $t=1993$ & $24^{\prime}$ & $124^{\prime}$ & 1636’ & 212’ & \\
\hline & $t=1996$ & 23 & $126{ }^{\prime}$ & 1693’ & $2200^{\prime}$ & \\
\hline
\end{tabular}

Source: Statistics Sweden (SCB). 